\title{
TOWARDS A PROPERTY REGISTRY 3D MODEL IN PORTUGAL: Preliminary case study implementation tests
}

\author{
José-Paulo de Almeida, Universidade de Coimbra* a, b, c, uc25666@uc.pt, +351 239791150 \\ Xiangyi Liu, University College Londonc, xiangyi.liu.12@alumni.ucl.ac.uk, +44 (0)20 7679 \\ 7224 \\ Claire Ellul, University College London ${ }^{\text {c }}$, c.ellul@ucl.ac.uk, +44 (0)20 76797224 \\ Maria Manuel Rodrigues-de-Carvalho, Câmara Municipal de Coimbra ${ }^{\mathrm{d}}$, maria.manuel@,cm- \\ coimbra.pt, +351239857500
}

\begin{abstract}
The 3D concept emerged as a key concept within geoinformation science. 3D geoinformation has been proved to be feasible and its added value over $2 \mathrm{D}$ geoinformation is widely acknowledged by researchers from various fields. Even so, 3D concept merits still need to be exploited further and more specific applications and associate products are needed - such as within property cadastre, our ultimate field of interest. The growing densification of urban land-use is consequently increasing situations of vertical stratification of rights. Traditional 2D cadastral models are not able to fully handle spatial information on those ownership rights in the third dimension, thus 3D cadastre has been attracting researchers to better register and spatially represent real world overlapping situations. A centralised distributed cadastral management system, implementing a 2D cadastral model, has been conceived by the national cadastral agency in Portugal: the so-called SiNErGIC. The authors seek to show that there is room though for further investigation on the suitability of a 3D modelling approach, incorporating both topologicalgeometric representation and legal/administrative components, capable of handling the overall multipurpose cadastral reality in Portugal. This paper focuses primarily on the clear identification of some case studies illustrating the pertinence of such an approach; first technical implementation tests were carried out.
\end{abstract}

Keywords: Multipurpose cadastre, 3D cadastral modelling, 3D property unit.

\footnotetext{
* Corresponding author.

${ }^{a}$ Dept. of Mathematics (Geomatic Engineering Lab.), Faculty of Science \& Technology, Apartado 3008, 3001-501 Coimbra, Portugal.

b Institute for Systems Engineering \& Computers at Coimbra, Rua Antero de Quental 199, 3000-033 Coimbra, Portugal.

${ }^{\mathrm{c}}$ Dept. of Civil, Environmental \& Geomatic Engineering, University College London, Gower Street, London WC1E 6BT, UK

${ }^{\mathrm{d}}$ Coimbra City Council, Cadastre \& Land Management Office, Pátio da Inquisição 7, 3000-221 Coimbra, Portugal
} 


\section{Introduction}

\subsection{General context: 3D geoinformation}

Most information needed by policymakers is related to locations on the Earth. Despite some practical difficulties, it is clear that 3D geoinformation is becoming increasingly important. Research has demonstrated the added value of 3D information over 2D in these cases: an overall more efficient integration of urban vs. regional planning and management especially dealing with $3 \mathrm{D}$ underground/aboveground infrastructures.

There has been consistent research within geoinformation science on the concept of 3D for more than a decade now. For instance, merits of 3D GIS techniques have been widely debated, tested, and have been proved to be quite advanced. Nevertheless, several individual parties potentially involved are still reluctant to invest in 3D data, 3D techniques, and applications. As a consequence, large administration processes relating to urban/rural planning often run up financial losses simply because geoinformation is not part of the process.

In spite of all the research undertaken, 3D geoinformation is a complex field and requires more advanced research and techniques to be especially used in complex administrative procedures (Stoter, 2011). In addition, more specific applications and associate products are needed. Geoinformation science is never a goal in itself, it is a "serving discipline", and without applications it may well turn useless (Stoter, 2011). Examples include: automated change detection; integration of voxel and 3D vector data; generation, from laser-scanned point data, of tree and/or building models, which can be easily integrated in OGC CityGML models; interactive airstream simulations; 3D city models; integrated geospatial planning and management of 3D underground/aboveground municipal assets; or 3D cadastre. 3D cadastre - in fact, our ultimate field of interest - certainly has to build on 3D geoinformation science: 3D GIS as a whole, 3D geospatial data, 3D topology, and 3D data-structures. Even so, there is the need to take it further in order to tackle specific needs and to be able to incorporate cadastral laws.

\subsection{Motivation}

Regardless of the country, federal state, or province, an up-to-date property cadastral system is fundamental for a sustainable development and environmental protection. It is indeed widely acknowledged to be the basis of a healthy economy, and hence the pertinence of such topic.

Current worldwide property cadastral registries use 2D parcels to register ownerships rights, limited rights, and public law restrictions on land. In most cases this is sufficient to give clear information about the legal status of property units. But in cases of multiple use of space, with stratified property rights in land, the traditional 2D cadastre is not, or only in a limited way, able to reflect the spatial information about those rights in the third dimension. As a matter of fact, the growing density of land use in urban context is consequently increasing situations of vertical demarcation between property units. Thus, 3D cadastre has been attracting researchers through out the world for nearly a decade now to better register and spatially represent real world overlapping situations.

As far as Portugal is concerned, a centralised distributed cadastral management system, which implements a 2D cadastral model, has been conceived: the so-called SiNErGIC. Nevertheless, its technical implementation is far from being concluded mainly because most of surveyed geospatial data, referring to coordinated cadastre, is still being acquired in the field and processed. Moreover, from several experiences across the world it is known beforehand that a 2D model has limitations for it is not capable of modelling and handling very well complex 3D situations. 
Every standard is generic in nature. Thus, the recently approved international standard ISO 19152 (November 1st, 2012) should be adapted to Portugal's cadastral reality. The standard model has to be conveniently applied in order to incorporate Portuguese Cadastral Law. The ultimate goal should be the implementation of a 3D cadastral model capable of handling the overall cadastral reality in Portugal. Ideally, further agreements between many stakeholders - ranging from governmental bodies, research centres, to commercial parties - should be achieved to assure optimal operability of such a model. As a result of such a nationwide agreement, a 3D national standard for large-scale topography should be set up.

\subsection{Aim and objectives}

In the light of the above, an investigation of $3 \mathrm{D}$ cadastre aspects appears to be pertinent both in the context of the Portuguese real estate law as well as in its geometrical side. The main aim of this research report is to discuss the pertinence of such an investigation and launch its bases. Some objectives of this paper were identified as follows:

- To start with, the review of both some historical circumstances and current status of the Portuguese property cadastre

- In order to illustrate the pertinence of a 3D cadastre approach, the identification of some instances where the current 2D cadastral model in Portugal is clearly limited

- Implementation tests of one of the identified case studies above.

\section{3D modelling in property cadastre}

\subsection{Elementary cadastral concepts and definitions}

Property cadastre information is usually managed by one or more government agencies. The central defining feature of any land management system is a property cadastre that states the record of all interests associated to land, describing in particular the rights, restrictions and responsibilities. A cadastral system may be established principally for three somewhat traditional purposes or functions (FIG, 1995):

- Fiscal, e.g. valuation and equitable taxation

- Legal, mainly in the support of legal transactions (conveyance)

- Territory management, e.g. to assist in urban/regional planning or other administrative purposes.

Regardless of being 2D or 3D, a cadastre is normally a land lot-based system, i.e. information is geographically referenced to unique, well-defined units of land - the so-called parcels. These parcels are defined by the formal or informal boundaries marking the extent of lands held for exclusive use by individuals or specific groups of individuals (e.g. families, inheritances, corporations, or any other communal groups). Graphical indices of these parcels, known as cadastral maps, show the relative location of all parcels in a given region. Cadastral maps commonly range from scales of 1:10 000 to 1:500. Large-scale diagrams or maps showing more precise parcel dimensions and features (e.g. buildings, irrigation units, etc.) can be compiled for each parcel based on ground surveys or remote sensing and aerial photography. Information in the textual or attribute files of the cadastre, such as land value, 
ownership, or use, can be accessed by the unique parcel code shown on the cadastral map, thus creating a complete cadastre (FIG, 1995).

\subsection{The overall need for a 3D modelling approach}

2D planimetric survey plans have been overall adequate and acceptable to property owners. With increasingly complex developments above and underground - where structures and usage of space cannot be seen in $2 \mathrm{D}$ - this is no longer the case. Even so, one may argue that the question is still open: is there in fact a real need for a 3D model for property cadastre purposes? As far as we are concerned, yes there is. The issue is not so much the need for simple 3D visualisation capabilities of a stratified reality - though a very much pertinent aspect. It should be emphasised that the real issue dwells in the linkage between a 3D geometry/topology infrastructure and legal concepts on stratified ownerships, which are far less tangible. In other words, the real difficulty is the materialisation of legal concepts that a human eye may well be aware of, but a 2D computerised system is in principle incapable of discerning.

Several authors (including Abdul-Rahman et al., 2012; Khoo, 2012; Soon, 2012; Stoter et al., 2012b; Wang et al., 2012; Ying et al., 2012; Zhao et al., 2012; Abdul-Rahman et al., 2011; Stoter et al., 2011; van Oosterom et al., 2011; Hassan et al., 2010; Chong, 2006; Stoter and van Oosterom, 2006; Valstade, 2005; Stoter, 2004; Stoter et al., 2004) have demonstrated that indeed 3D representations of airspace and subterranean parcels are currently required given that $2 \mathrm{D}+$ half representations are unable to handle $3 \mathrm{D}$ measurements, spatial queries, or visualisation. As reviewed in section 3.3, 3D cadastral technology has emerged recently. There has been considerable research over the past decade on the founding aspects of 3D cadastres, and some pilot studies have been accomplished so far. Victor Khoo (2012) summarised the main aims to be achieved in implementing a 3D cadastral system, as follows:

- To adopt an official and authoritative source of 3D cadastral survey information

- To adopt open source format for data exchange and dissemination

- To adopt international standards in data modelling

- To design a smart data model that supports "3D parcels" (vd. definition in section 2.3)

- To automate cadastral survey data processing and official approval

- Finally, to introduce a 4th dimension related to time towards a 4D data model.

In terms of possible 3D cadastral models, Stoter and van Oosterom (2006) investigated and proposed three different possible approaches: full 3D cadastre, in which the entire space is subdivided into volume parcels and 3D rights are fully supported by the legislation and cadastral registration; hybrid cadastre, where $2 \mathrm{D}$ cadastre is preserved integrating however $3 \mathrm{D}$ situations whenever needed by registering them as part of the 2D cadastral dataset; 3D tags linked to parcels in current 2D cadastral registrations, i.e. 3D situations are represented externally referenced though to an existing 2D cadastral system.

\subsection{Dpatial and semantic information}

In the light of the international standard ISO 19152, on the Geographic-information Land Administration Domain Model (LADM), the notion of 3D cadastre with 3D parcels has to be understood in the broadest possible sense. What a 3D parcel exactly is, or could be, may well depend upon both the legal and organisational context of each specific country (or state/province). The broad meaning of a 3D parcel 
includes land and water spaces, both above and below surface. Nevertheless, a formal definition can be given as follows: "a 3D parcel is defined as the spatial unit against which one or more homogeneous and unique rights (e.g. ownership right or land use right), onus or restrictions are associated to the whole entity", as included in a Land Administration system (ISO/TC211, 2012).

The term "homogenous" above means that the same combination of rights equally applies to the whole 3D spatial unit; furthermore, "unique" means that it is the largest spatial unit for which the above is true. Hence, making the unit any larger would result in the combination of rights not being homogenous; making the unit smaller would result in at least 2 neighbour 3D parcels with the same combinations of rights.

A 3D parcel always refers to a "legal object" describing simultaneously a "part of the space". Thus, in general property cadastres there are two different types of objects: the legal and the spatial ones. Often there is a direct relationship between a legal and a real world spatial object. It is the spatial object that in turn may be also described in 3D. More precisely, the focus in the context of 3D cadastres is on 3D parcels understood as "spaces of legal objects".

Accurate collection methods of 3D spatial data are required so that relevant data acquired at a specific time may be incorporated in a 3D data infrastructure. Spatial data may refer to information such as on: the ownership number; the parcel's unique identifier; the parcel's geometric shape and area; if it is the case, on the footprint of manmade constructions, e.g. buildings, within the parcel; building geometry; each building's floor area (Hassan and Abdul-Rahman, 2010, cited in Abdul-Rahman et al., 2012). As far as semantic information is concerned, this has to be rich enough in order to provide a description about the parcel as detailed as possible, such as: owner identity, e.g. name and national tax number; parcel history; number of physical components; type of lease; if it is a building, number of floors, or volume space. In 3D modelling, implicit or explicit geometry may well be used to generate the 3D model itself. With this regard, the integration of Building Information Models (BIM) can also help in data collection process, though this should only be carried out if the integration of both CityGML and IFC standards can be achieved (Abdul-Rahman et al., 2012). The spatial unit package defines spatial units as being 2D (land parcels) or 3D (space), buildings, or utility networks. These include in turn topological, polygon, line, point, and text spatial units (ISO/TC211, 2012).

\subsection{An overview of 3D modelling approaches in cadastral systems}

Further to the International Federation of Surveyors (FIG) congress in April 2002, some work has been devoted to 3D aspects of cadastral registration systems both in a fundamental way and at an international level. This has been done mainly in the context of a working group set up as a joint sub-group of Commission 3 and Commission 7 of FIG - which is in turn subdivided into three sections dealing with the legal, institutional, and technical aspects of $3 \mathrm{D}$ cadastre respectively.

The joint sub-group above has promoted so far three international workshops: Netherlands, Nov 2001 (www.gdmc.nl/events/3dcadastres2001); Netherlands, Nov 2011 (3dcadastres2011.nl); China, Oct 2012 (www.cadastre2012.org). A wide range of papers have been presented throughout those workshops on 3D modelling approaches towards what has been defined as "smart cadastre" that supports 3D parcels (Khoo, 2012).

Before 3D approaches towards 3D cadastres were actually conceived and implemented, there was initial work some time ago reviewing the status of different cadastres across the world. Back in 2004, Steudler et al. (2004) started a worldwide comparison of cadastral systems. In the context of a comparative analysis on the cadastral systems in the European Union (EU), Manthorpe (2004) carried out a review on the UK 
really. In turn, starting off from a comparative analysis of cadastral systems across the European continent, Valstade (2005) undertook a similar study in Norway. Yavuz (2005) carried out possibly the first comparative analysis of cadastral systems in European Union (EU) countries according to basic selected criteria.

In the meantime, there has also been considerable research for more than a decade now on the foundations of 3D geospatial data-structures as a whole, not necessarily towards 3D cadastral systems. Several authors have worked specifically on the identification of possible topological relationships in the 3D context and their validation. For instance, by considering two-dimensional topology and modelling as a starting point, Gröger and Plümer (2005) took it further in order to be able to deal with topological concepts and models that are necessary to represent three-dimensional urban objects in a geographical information system (GIS). Ellul et al. (2005) initially derived a generic topological datastructure for 3D data, and defined the fundamental requirements for the implementation of topology in 3D GIS (Ellul et al., 2006). Further to the need for efficient and scalable techniques for storage, validation and query of 3D models in terrestrial data management, Kazar et al. (2008) focused on the problem of validation of 3D geometries, and presented an Oracle's data model for storing 3D geometries. Verbee and Si (2008) employed "constrained Delaunay tetrahedralisation" to check the validity of a single 3D polyhedron. Ellul et al. (2009) reviewed the 9intersection framework for boundary representation in 3D GIS, and then outlined modifications to that structure to improve binary relationship query performance. Brugman et al. (2011) developed a series of topological rules to validate a 3D topology structure for a 3D space partition. Having in mind their application to 3D cadastre in particular, Thompson and van Oosterom (2011a, 2011b) in turn extended Brugman et al.'s rules to axiomatic definitions to validate a 3D parcel and its relationship with adjacent 3D parcels within a space partition. By defining an axiomatic characterisation of 3D city models, Gröger and Plümer (2011a) worked on consistency checking tools to assess the suitability of spatial data for their applications.

As far as 3D cadastre in particular is concerned, Stoter and van Oosterom (Stoter, 2004; Stoter and van Oosterom, 2006) have analysed the needs and opportunities for a 3D cadastre. Starting from the Dutch cadastral reality, these authors set up one of the very first frameworks for modelling both 2D and 3D cadastral situations in a worldwide context, and developed a general prototype model for a 3D cadastre. Karki et al. (2011) specifically discussed geospatial data validation in 3D cadastre including a single 3D parcel and its relationships with other 3D parcels. Further to Verbee and Si (2008), Brugman et al. (2011), Thompson and van Oosterom (2011), and Karki et al. (2011a), Zhao et al. (2012) proposed a novel method towards the validation of spatial relationships among 3D parcels, by identifying either correct or even incorrect topological relations in 3D. Furthermore, geovisualisation aspects in 3D cadastre have been also tackled. Wang et al. (2012) have been working on the visualisation principles in 3D cadastres and investigated which variables among visual variables are appropriate for geovisualisation of 3D legal units in a 3D cadastre system. In 2011, van Oosterom et al. accomplished a worldwide inventory of the status of 3D cadastres in 2010 and stated what the expectations were for 2014.

Other authors have developed in turn relevant work on the extension of 3D GIS to 3D cadastre. 3D GIS offers indeed some techniques that can be directly applied in 3D cadastre - for instance, 3D GIS provides proper methods for the representation of geometry of 3D cadastral objects and to associate to them property rights, semantics, and transaction attributes. Nevertheless, other techniques should be improved in order to be able to deal with management operations within 3D land administration. This is mainly because 3D GIS and 3D cadastre objects are different. For instance, Gröger and Plümer (2011b) extended the axiomatic characterization of 3D surfaces proposed by them (Gröger and Plümer, 2011a), which guaranteed consistency between geometry and topology, to the case of "handles" (e.g. tunnels, bridges, or 
arcades); by doing this, the authors closed the gap between the global topological definition of handles in surfaces and the local definition of semantical handle objects in GIS. Frédéricque et al. (2011) presented a benchmark exercise in which an architecture, combining both desktop GIS applications with server based RDBMS, was used to implement different scenarios for a 3D Cadastre (full 3D and hybrid); results obtained by the authors illustrate how possible it is to combine advanced CAD and GIS technologies to create and update intelligent objects corresponding to both 3D urban features and 3D property units. Ying et al. (2012) applied 3D GIS techniques to 3D cadastre in urban environment as an attempt to build the bridge and fill the gap between urban simulation and urban space management; details of such application were elaborated through three main aspects: 3D data and 3D modelling, 3D simulations and 3D visualisation, practice and decision-making support.

Furthermore, a remark should be done on the increasing prevalence of building information models (BIM). New technologies on BIM are continuously being developed which means that we can expect to see very detailed building models available in the planning stage. Consequently, these models appear to be useful to generate 3D volumes for properties (Frédéricque et al., 2011; Smith, 2012).

More recently, various pilot 3D cadastre systems have been developed and tested for the specific cadastral context of some countries, like: Australia (Karki et al., 2011b), Brazil (Barros-de-Souza, 2011), China (Guo, 2011), Korea (Jeong et al., 2011), Malaysia (Abdul-Rahman et al., 2012), Russia (Vandysheva et al., 2011), Singapore (Khoo, 2012; Soon, 2012), or The Netherlands (Stoter et al., 2011, 2012b).

Finally, as far as Portugal's cadastral context is concerned, Hespanha et al. (2006) worked on the evaluation of an initial FIG core cadastral model (Lemmen et al., 2003) by applying it to Portugal's cadastre. Based on that previously proposed standard, an object oriented, conceptual model for the cadastral domain was then adapted to the Portuguese cadastre and associate real estate registry "Registo Predial". Their approach however covered essentially the 2D reality and needs to be taken further towards 3D cadastral modelling purposes.

\section{Portugal's property cadastre}

\subsection{Historical aspects and current status}

The first official step towards the establishment of a national registry of land parcels in Portugal was taken in 1801. By royal decree, all cosmographers (one who studies, describes, depicts, and measures the Earth and/or the visible universe, including geography and astronomy) of the kingdom were appointed then to be in charge of the organisation of both a cadastre and a general registry book of all properties existing in the kingdom. The fact that those practitioners were the ones in charge of accomplishing such a task clearly states how aware authorities were in those days of the great value of a coordinated cadastre. For several reasons, such a registry was never launched though until 1836, when the national property registry ("Registo Predial") actually started being implemented (Silva et al., 2005). Like in many other countries across the world, the Portuguese property registry system is based on the "folio principle", i.e. each "land parcel" on the ground is related to exactly one ownership title registered in the land registry. Every land parcel has a unique parcel identifier number to which all parcel-relevant information is linked. The term "property" as such is not used in the Portuguese legislation, though the equivalent word does exist in Portuguese, "propriedade", but is more informally used in everyday language. The official term used, as explained below, is "prédio" (from the Latin word "prædium", standing for real estate or legal immovable property unit). 
Like other property parcel registries across the world, "Registo Predial" has been serving in Portugal as the pillar foundation for property transactions and for securing the legal status of property boundaries. Even though the registration of propertiess has been in theory mandatory since the registry was launched, in practical terms this was not really the case unless any legal transaction over a given parcel was in fact to be undertaken. In general, however, propertiess in Portugal are historically likely to be passed on through generations by simply being inherited. They would be rarely sold/bought and it was not indeed until roughly the 1980s that such transactions became more common. As a consequence, many propertiess are still omitted from the registry. Authorities are however somewhat in control of the situation for the national revenue and customs agency (ATA - "Autoridade Tributária e Aduaneira") is in charge of up-todate records for taxation purposes, the so-called "Matriz Predial", on the nearly 17 million propertiess in the country.

Like other cadastres across the world, Portugal's cadastre also follows a property-based approach. In the Portuguese jurisdiction, a "prédio" can be classified into one of the three following possible types (Mendes, 2003):

- "Prédio rústico" (Rural property unit) - which may be situated either in rural or urban areas. The main characteristic of this type of properties is that they are not meant to be subjected to any sort of construction development, and hence are principally devoted to agriculture or forestry activities. Besides land lots, this parcel type may also include water bodies and crops (separate from the land lot where they happen to lie on).

- "Prédio urbano" (Urban property unit) - which are situated only within urban areas only. This type of property includes any manmade construction (i.e. meant for residential, commerce, industrial or services purposes), and may also include land lots meant to be developed.

- "Prédio misto" (Mixed parcel unit) - Although rare, this is a very specific type to classify those properties that have both rural and urban characteristics and none of them can be identified as the main one.

Since both national records were implemented, cadastral information of both "Registo Predial" and "Matriz Predial" is based on text. Each property unit is geo-referenced by explicit reference to its northern, southern, eastern and western neighbouring parcels or geospatial features (e.g. roads, railways, water bodies, etc.). This is what actually still happens in most instances, as the coordinated cadastre is currently still being surveyed. Cadastral survey was launched in 1926 by the national mapping \& cadastral agency and has not covered the whole country yet. It has been indeed a rather complex and demanding operation to undertake given Portugal's territory tissue: a country of a few millions of literally microscopic properties, especially in the mainland's northern-half, also in Azores and Madeira archipelagos. Fig. 1 and Fig. 2 below illustrate respectively examples of a cadastral section map produced in the early $20^{\text {th }}$ century and a more recent general cadastral map digitally produced. 


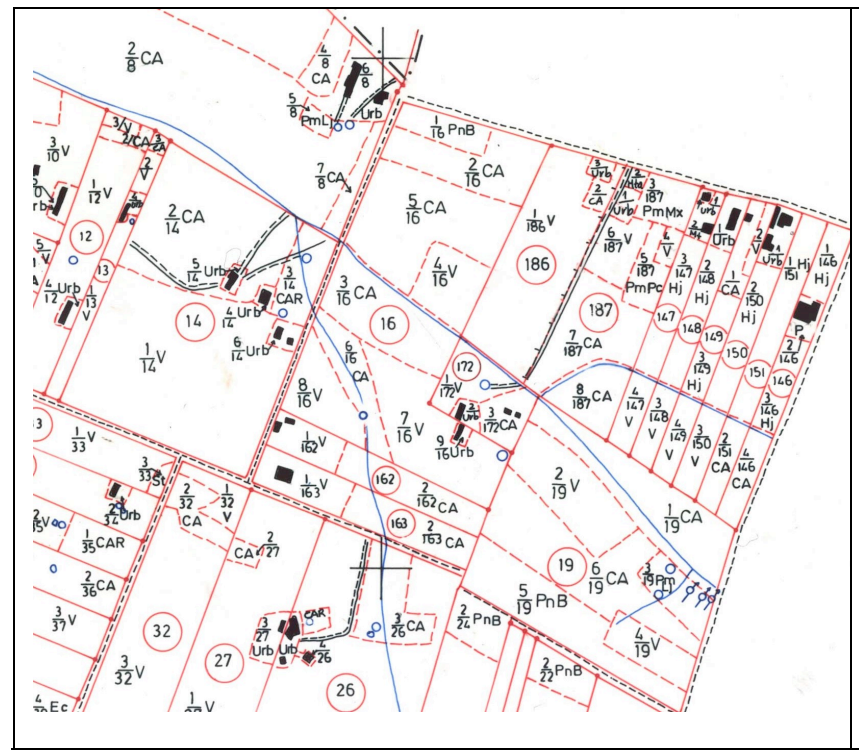

Fig. 1 Map of a cadastral section produced early $20^{\text {th }}$ century (source: DGT - Portugal's mapping \& cadastral agency)

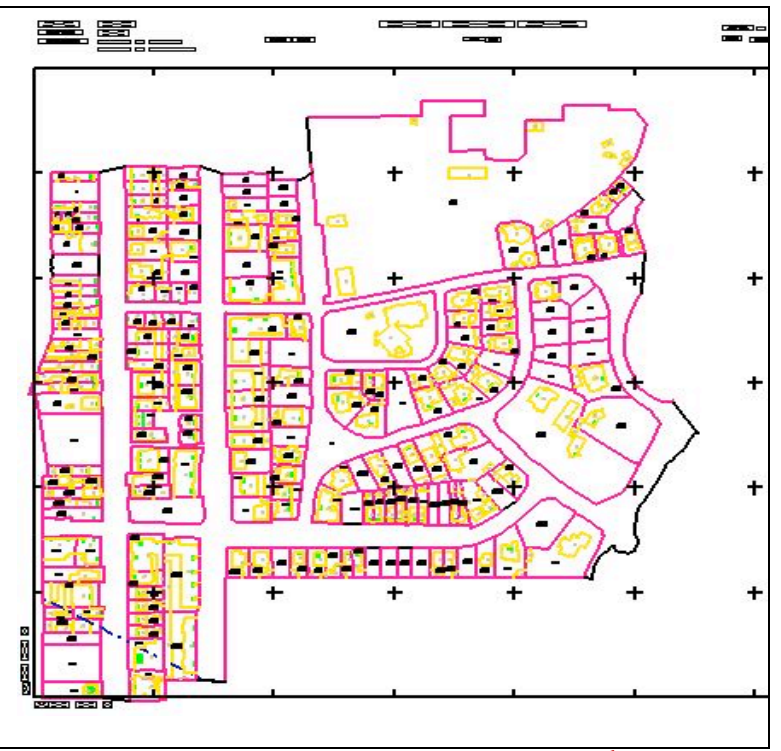

Fig. 2 Cadastral map produced late $20^{\text {th }}$ century (source: DGT - Portugal's mapping \& cadastral agency)

Cadastral surveying started off in the mainland's southern-half, where one of the main sources of the country's economy in the first half of the $20^{\text {th }}$ century was: the "latifundium" (the Latin word standing for a large landed farming estate). That is why it only covered rural properties then; urban properties were never surveyed until a pilot experiment was carried out between Jan 2006 and Feb 2008 in one of the civil parishes of Pombal district, Albergaria-a-Velha (mainland's west-centre). This was a key step towards cadastre modernisation. Since then, Portugal has embarked on various other initiatives to modernise its cadastral survey. Cadastral surveying is currently being accomplished district-by-district covering both kinds of properties, rural and urban. As depicted in Fig. 3, by the end of 2011 more than $50 \%$ of the mainland was surveyed, though this only corresponds to roughly $1 / 3$ of the total number of properties in the country. Currently, 7 districts are being surveyed in Portugal's mainland: Paredes and Penafiel (in the northwest); Oliveira-do-Hospital and Seia (in the centre); Tavira, São-Brás-de-Alportel and Loulé (in the Algarve). 


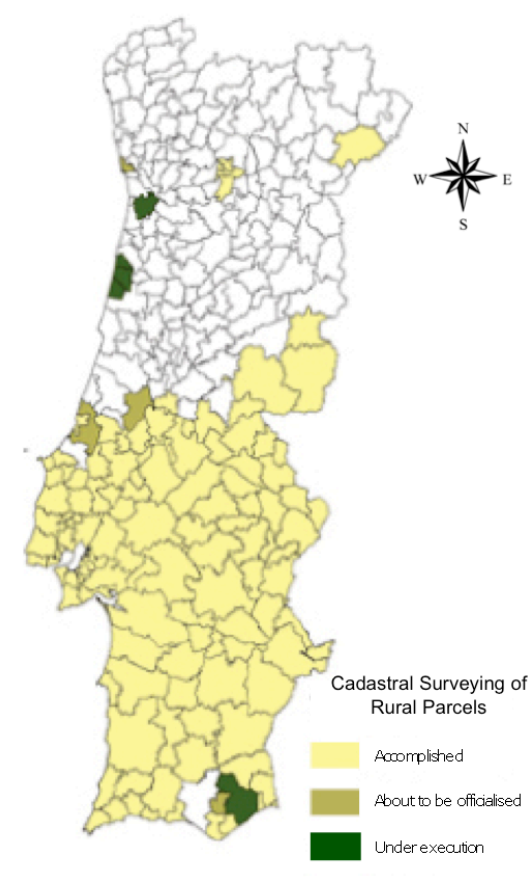

Fig. 3 Portugal's mainland districts and progress on cadastral surveying of rural properties by 2012 (source: DGT - Portugal's mapping \& cadastral agency)

\subsection{The future: SiNErGIG}

Overall, property cadastre has been traditionally serving the basis for both taxation and legal purposes. These functions are indeed of most relevance within any country's economy, will not change as such and hence will continue to be significant. A third requirement for cadastre has emerged more recently: urban/regional planning. It is within this context that cadastral survey information became even more crucial. Given its level of detail and amount of data, cadastral survey information constitutes nowadays the most critical land base information to support development and planning in governance (Khoo, 2012).

Aware of the facts above, the Portuguese government took an historical decision in 2006 towards the implementation of a centralised distributed - through the World Wide Web - cadastral management system (formalised by Cabinet Resolution nr. 45/2006): the design and implementation of the so-called SiNErGIC (PCM, 2006). The main goal of such a system is to make available the existence of a multipurpose cadastral system in Portugal setup as an "exhaustive, methodical, and up-to-date set of data able to uniquely identify and describe property parcels" (DGT, 2012).

The main objectives of SiNErGIC can be summarised as follows (PCM, 2006):

- To unify and concentrate within a single system both current and future cadastral data

- To assure its compatibility with other institutions' electronic systems involved in this project

- To assure unique identification of each property unit

- To assure that each property unit's description includes a digital graphical plan 
- To assure its dissemination and usage by general state administration - subject though to specific permissions and protocols

- To assure both citizens and companies general access to the system - again, subject to specific permissions and protocols.

Because cadastral surveying has been taking so long to cover the whole country, what has actually been happening since the middle 1970s is that several private construction companies and state agencies directly intervening in territorial operations have technically undertaken themselves cadastral surveys as needs arise. In particular, local municipal authorities are in possession of virtually all construction plans within their territorial jurisdiction.

The facts above led to a further central government's decision, formalised by Cabinet Resolution nr.56/2012 (PCM, 2012a). While formal cadastral surveys are being carried out in the field, a nationwide repository of geospatial data currently owned by both public and private sectors shall be set up (PCM, 2012a):

- To be processed and checked against cadastral standards towards its eventual official approval

- To be articulated and incorporated thereafter into the official property cadastre registry.

Further to all governmental decisions above, efforts have also been taken in fact towards existing cadastral data crossing principally from both "Registo Predial" and "Matriz Predial". Thus, a merging of both national records is currently ongoing. These cadastral data will be indeed the pillar foundations of the future SiNErGIC.

\subsection{Towards a 3D modelling approach}

Recent encouraging governmental decisions described in section 3.2 above are vital when envisaging a centralised cadastral management system. Nevertheless, 3D aspects of cadastral data towards a possible 3D cadastral system have not been covered in SiNErGIC.

As elsewhere in the world, many examples can be identified in Portugal's context where the 2D cadastre is limited. For instance, the work being currently accomplished by Coimbra city council (CMC - "Câmara Municipal de Coimbra") can be placed amongst the initiatives undertaken by some state institutions as that described in section 3.2 above. Preliminary discussions between the authors and some CMC staff (particularly from its cadastre and land management office - "Gabinete de Cadastro e Solos", GCS), allowed the identification of some case studies. Six of these case studies identified so far are presented in this section in order to demonstrate the pertinence of a 3D cadastral modelling approach. They correspond to different somewhat complex cadastral situations detected specifically in the city of Coimbra, several instances of such cases, or similar ones, can be found though across the country.

Before case studies are presented, we shall define in here the concept of some cadastral spaces that are part of the Portuguese cadastral law. Therefore, for the purposes of this study, "municipal domain" (corresponding in the Portuguese legislation to "domínio privado municipal") stands for state rights over a particular real estate - land parcel or manmade infrastructure - owned by the local city/town council whose jurisdiction covers the district territory where the given property happens to be located; "public domain" (in the Portuguese legislation, “domínio público”) stands for citizenship rights over the general 
public space - managed though by a specific state agency, depending on each instance; "private domain"(in the Portuguese legislation, "domínio privado particular") stands for private rights over a particular real estate - land parcel or manmade infrastructure - owned by a single or any sort of corporate person

\subsubsection{Case studies}

\subsubsection{Case study 1: "Dom Pedro V" lift/funicular}

"Dom Pedro V" lift/funicular is constituent part of the public transport system in the rather hilly city of Coimbra - west-centre of Portugal's mainland. Built in 2000, and started operating in 2001, it is owned by the city council and is run by the local transport municipal company, SMTUC. The whole infrastructure consists of a $20 \mathrm{~m}$ vertical lift, a $24 \mathrm{~m}$ overpass, plus a $51 \mathrm{~m}$ sloping funicular connecting "Dom Pedro V" market area, in Baixa (which stands for downtown in Portuguese), to Alta (uppertown in Portuguese) where the historical and main campus of the University of Coimbra is located.

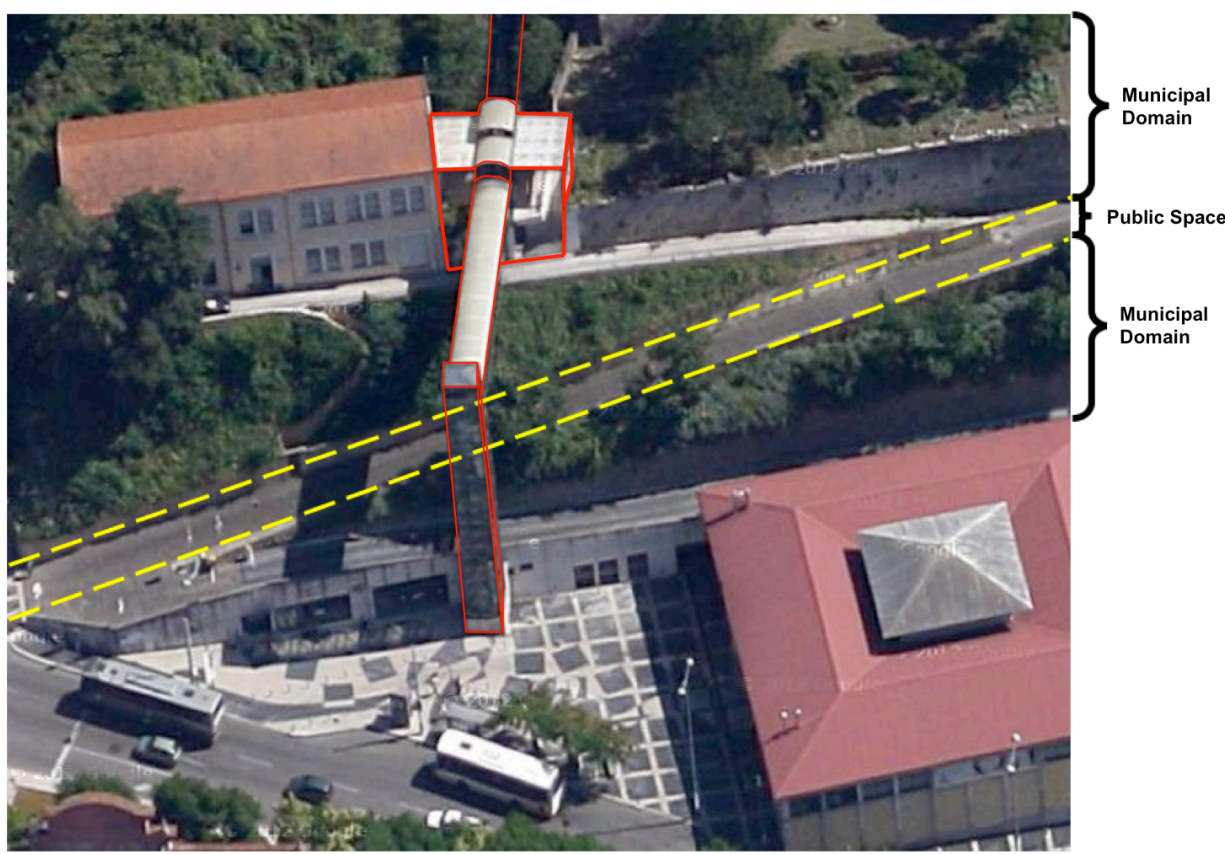

Fig. 4 Complex 3D cadastre occurrences in Coimbra (Portugal): GoogleEarth bird's eye view of the pedestrian overpass ("Dom Pedro V" lift/funicular) over both public domain and municipal domain

As illustrated in Fig. 4, the overpass in particular raises a clear example of a 3D issue in terms of cadastre. The whole infrastructure itself constitutes "municipal domain"; both the vertical and funicular lie on municipal domain; however, the overpass goes over public domain relating to the road underneath (in dashed yellow lines).

\subsubsection{Case study 2: "Pedro e Inês" pedlestrian bridge}

"Ponte Pedro e Inês" is a pedestrian bridge over the river Mondego connecting both sides of the so-called "Parque Verde do Mondego" (Mondego green park) on both riverbanks. 


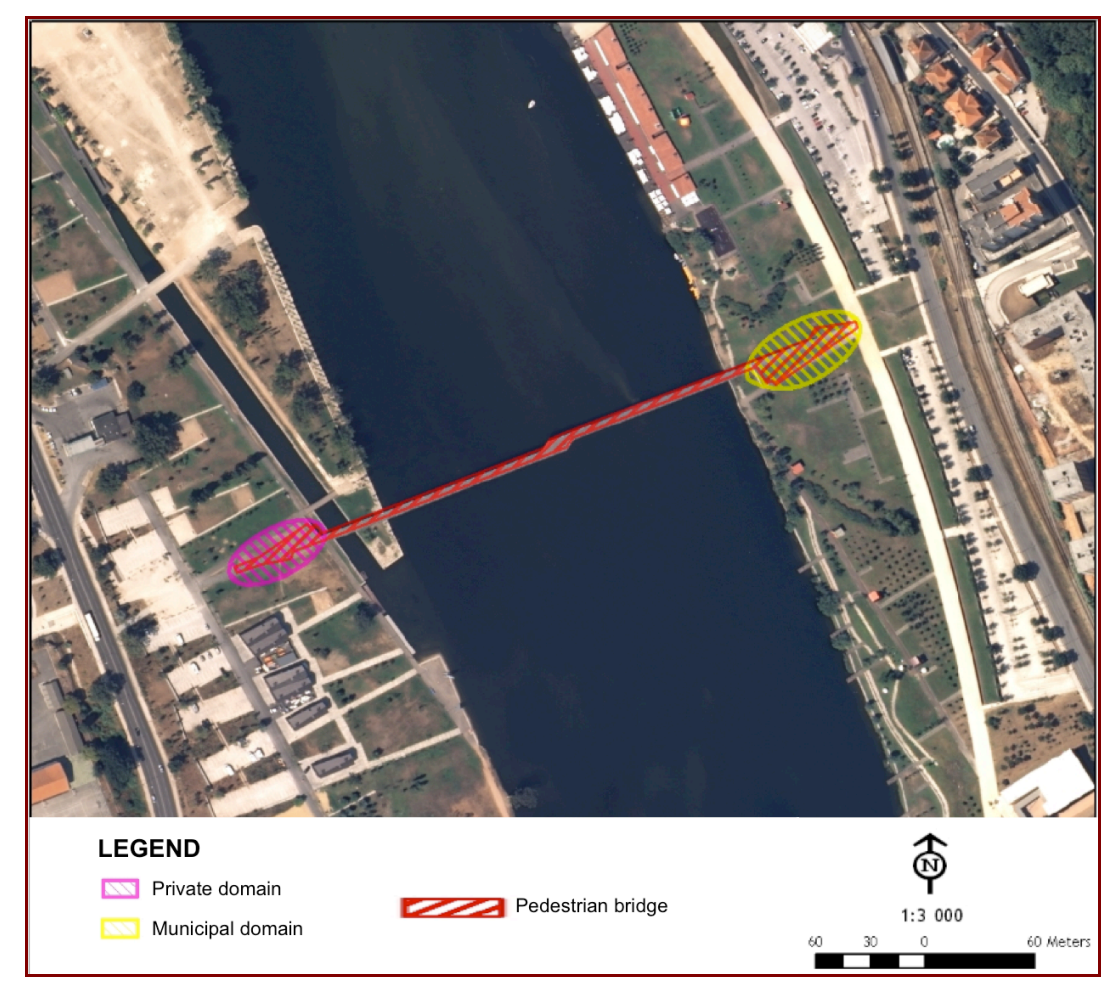

Fig. 5 Complex 3D cadastre occurrences in Coimbra (Portugal): 2D map of Mondego green park and "Pedro e Inês" pedestrian bridge (in red) standing on different types of land parcels on each side.

Like in case study 1 above, the pedestrian bridge infrastructure constitutes itself municipal domain. The interesting particularity of this case study is the fact that the south bank bridge's foundations (left-hand side of the picture) constructed in "private domain"; in turn, on the north bank (right-hand side of the picture), the infrastructure lies on municipal domain. Importantly, the private property above was not object of expropriation; nevertheless, the simple existence of a public infrastructure defines by law both: a buffer around it (which is indeed a 3D buffer where private rights are limited), and also establishes state right of way running across private land.

\subsubsection{Case study 3: private garages vs. public roof}

A third situation is presented. This case study covers a 3D cadastral instance in a residential neighbourhood where, very much induced by the local orography, a couple of rows of private garages are located under public surface. As illustrated in Fig. 6 below: garages are not underground; they are accessed via a local road, hence public domain; their roof happens to be the ground of an upper public terrace. 


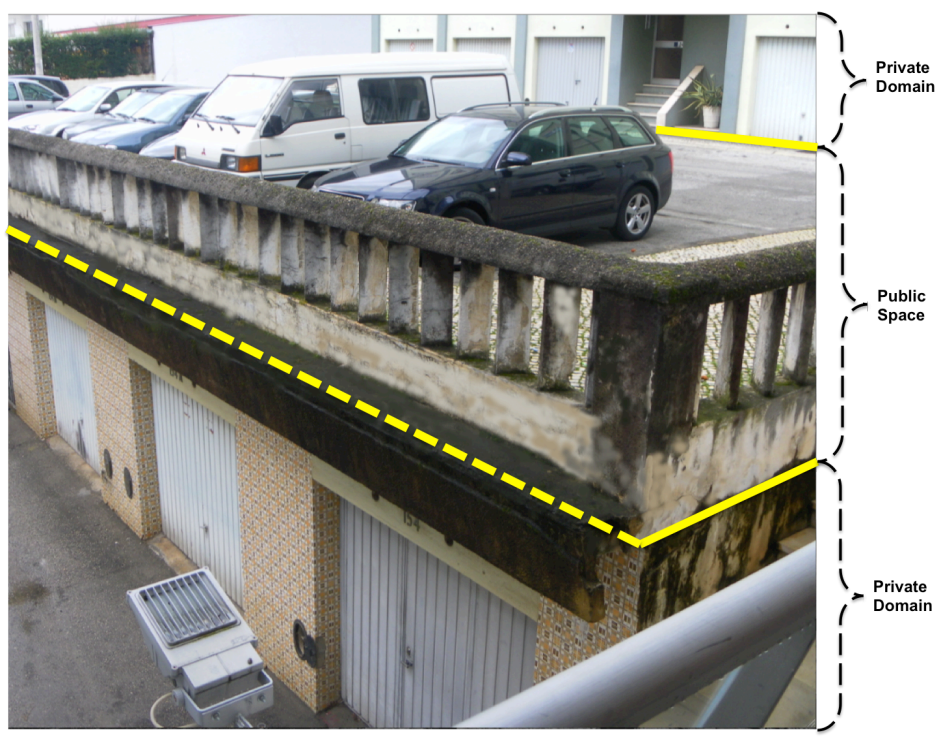

Fig. 6 Complex 3D cadastre occurrences in Coimbra (Portugal): private garages in a residential area under public space domain roof

\subsubsection{Case study 4: single flat shared by different buildings}

This case study refers to a very much common situation especially within the medieval pattern of ancient neighbourhoods that characterise most of the Portuguese towns and cities. There are instances where a flat though mostly contained by a given building happens to incorporate a room that physically belongs to a next-door building. In other words what happens is that, physical structures of buildings and "their" flats do not actually coincide.

For illustration purposes, let us have a look at the hypothetical situation depicted in Fig. 7 below. A flat on the first floor left of the light-grey building (represented by the dashed black line), is supposingly contained within this building. However, it includes a room that physically happens to be located inside the next-door white building. Such a situation turns to be even more complex for it cannot be visualised from outside. How can such an unexpected case be handled by a computerised cadastral system?

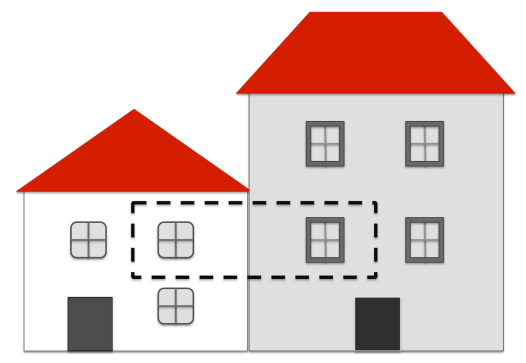

Fig. 7 Complex 3D cadastre occurrences in the medieval Coimbra downtown (Portugal): a flat shared by two buildings. 


\subsubsection{Case study 5: underground property unit underneath several different properties}

In this case, the issue is to some extent related to that in case study 1 above: property units and the physical infrastructure of buildings do not coincide.

The situation depicted in Figure 6 below relates do an underground communal garage that does not coincide with the underground infrastructure of the building it "belongs to". According to the Portuguese law, ownership rights over a given real estate on the ground also apply to the underground area underneath that property. As it may be seen in Fig. 8, those rights do not apply to the white building on the left for its underground area is taken by the communal garage that actually belongs to the light-grey building on the right. Again, as in case study 1, such a situation turns to be even more complex for it cannot be visualised from outside. How can a computerised cadastral system be capable of handling exceptions to the cadastral law like this one?

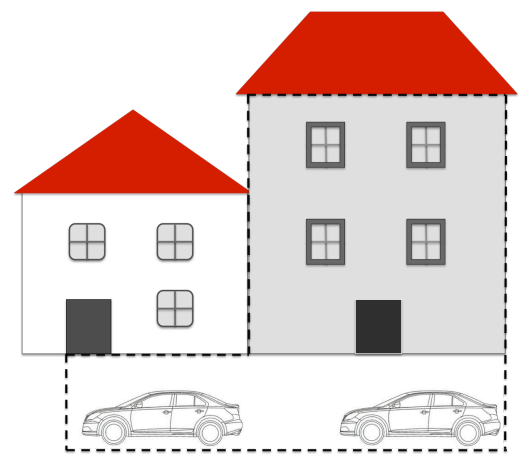

Fig. 8 Complex 3D cadastre occurrences in Coimbra (Portugal): underground garage underneath a nextdoor building

\subsubsection{Case study 6: arch-buillding of private flats over public space}

Finally, a sixth situation is presented. This case study covers another exception to the cadastral law in Portugal. As a principle, according to the Portuguese cadastral law, ownership rights over a given real estate on the ground also apply to both the areas, above and underneath that property.

In Fig. 9 below, the block of apartments illustrated is an arch-building over an urban road. This constitutes an exception to the legal principle above. Indeed, condominium ownership rights cannot be applied to the overground area underneath the arch-building since this constitutes public domain. Once again, how can a computerised cadastral system be capable of handling exceptions to the cadastral law like this one?

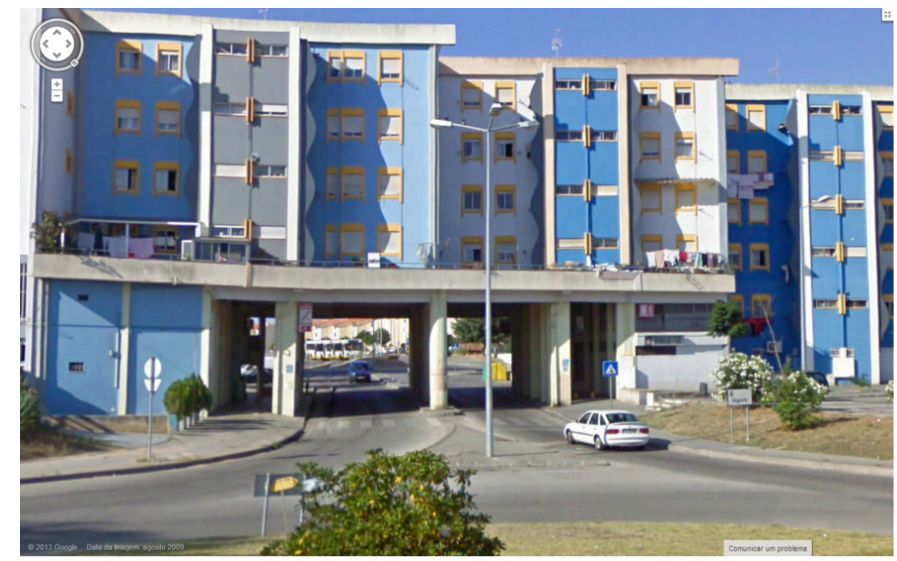


Fig. 9 Complex 3D cadastre occurrences in Coimbra (Portugal): arch-building of apartments (private property units) over an urban road (public space) - (source: GoogleEarth)

\subsubsection{Preliminary case study implementations}

In this section, details on the design and technical implementation of the case studies afore identified are described. For illustration purposes, we shall present results obtained for case study 6 (Section 3.3.1.6) given the fact that this was the one that possibly raised more interesting issues worthy of being discussed.

The Land Administration Domain Model (LADM) was developed by the Technical Committee 211 (TC211) as an international standard at the International Standardization Organisation (ISO), and has been finally approved by ISO on $1^{\text {st }}$ November 2012 (Bydłosz 2012). LADM provides reference models, terminology and solutions for land administration system modelling. It also gives the reference representation of spatial units (both $2 \mathrm{D}$ and $3 \mathrm{D}$ ) and solutions to represent space that is situated in the threshold between 2D and 3D parcels (Bydłosz 2012, ISO/TC211 2012). The conceptual model schema provided by LADM consists of five main packages (ISO/TC211 2012, Bydłosz 2012, Lemmen 2012, Lemmen et al. 2010):

- Parties (people and organisations)

- Rights, responsibilities and restrictions (RRR)

- $\quad$ Spatial units (parcels, buildings etc.)

- Spatial sources (e.g. surveying)

- Spatial representation (geometry and topology).

LADM is written in Unified Modelling Language (UML) and the diagram depicted below in Fig. 10 shows the core classes for LADM and their relationships, in which there are four basic classes: LA_Party, LA_RRR, LA_BAUnit and LA_SpatialUnit. In order to understand the model depicted in Fig. 10, let us take a simple example (Lemman et al. 2010): Oosterom, a LA_Party, has LA_RRR ownership on LA_BAUnit Oosterom's estate consisting of two (2) LA_SpatialUnit parcels (with same LA_RRR).

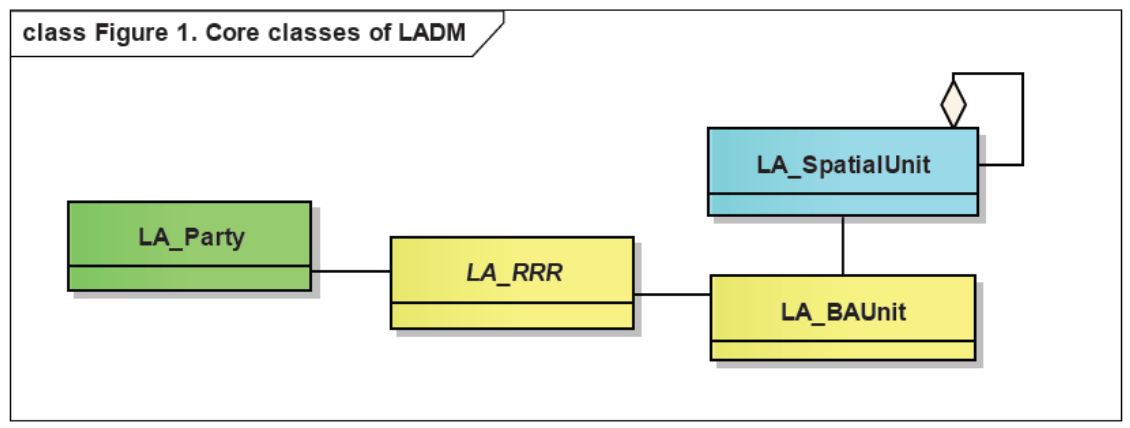

Fig. 10 LADM core classes and relationships (ISO/TC211 2012)

\subsubsection{The conceptual, logical \& physical models}

Our 3D cadastral model aims at describing the overall relationships between 3D legal objects and owners. The conceptual model was designed based upon the core model of LADM (Liu 2013), and consists of four main entities: Owner, Ownership, Basic_Building, and Part_Geometry. Their definition and corresponding entities in LADM's core classes are summarised below in Table 1. Although current 
Portuguese cadastral legislation does not fully support 3D ownership rights and restrictions, a full 3D cadastral law was assumed for our study purposes.

Table 1 Conceptual model's entities, their definition, and corresponding LADM classes (after Liu 2013)

\begin{tabular}{|l|l|c|}
\hline \multicolumn{1}{|c|}{ Entity name } & \multicolumn{1}{c|}{ Definition } & LADM class \\
\hline OWNER & A single or corporative person & LA_Party \\
\hline OWNERSHIP & $\begin{array}{l}\text { The ownership between the } \\
\text { owners and building objects }\end{array}$ & LA_RRR \\
\hline BUILDING & $\begin{array}{l}\text { A building infrastructure } \\
\text { object }\end{array}$ & LA_BAUnit \\
\hline PART_GEOMETRY & $\begin{array}{l}\text { A basic spatial 3D geometric } \\
\text { unit }\end{array}$ & LA_SpatialUnit \\
\hline
\end{tabular}

For the time being, general entity attributes were considered for implementation test purposes. These can be extended as needed according to specific cadastral laws. Fig. 11 depicts the logical model in which entities were abstracted as tables whose columns in turn correspond to the main attributes considered for each entity. Primary key and possible foreign keys were identified as constraints in each entity case.

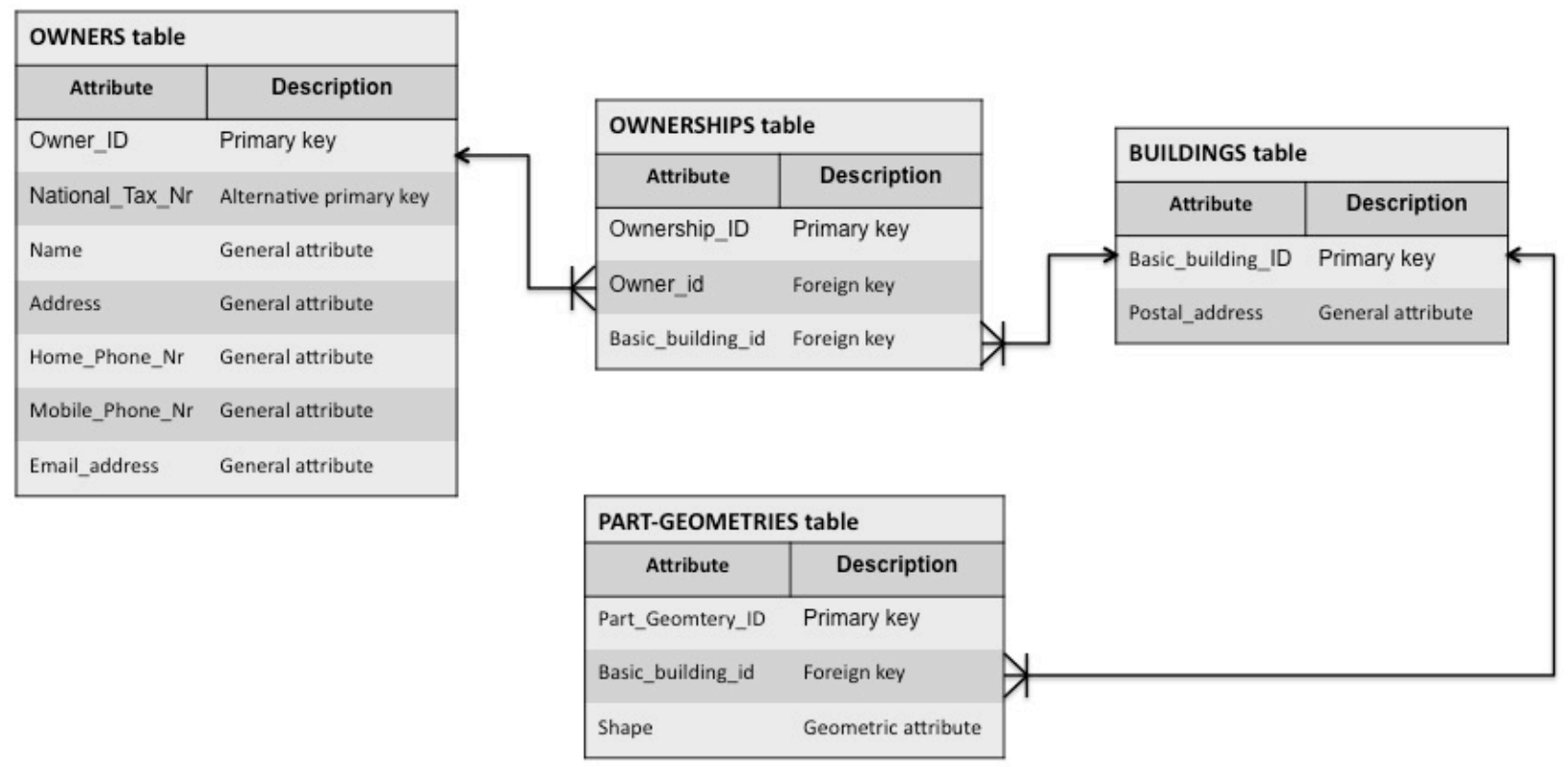

Fig. 11 Diagram of the logical model: entity tables, their attributes, and their relations (after Liu 2013)

In designing the physical model, geospatial data were transferred into a database management system (DBMS) - for our purposes, Oracle v.3.2.20.09. This phase consisted of a couple of steps that can be summarised as follows:

1. SQL was used to create entity tables depicted above, associate primary and foreign keys; 
2. Given the fact basemap data available was $2 \mathrm{D}$ data, the $3 \mathrm{D}$ occurrences were identified by combining different sources of data like 2D basemaps, GoogleEarth imagery and photography 2D basemaps were imported into the FME (Feature Manipulator Engine) Data Inspector in which feature point $(\mathrm{x}, \mathrm{y})$ coordinates were retrieved;

3. Initial sketches were manually drawn as geometric abstractions of the case studies' real infrastructures - these have the same appearance as that of the 3D models to be shown on the computer screen;

4. 3D coordinate values $(\mathrm{x}, \mathrm{y}, \mathrm{z})$ were derived for each object point - in all case studies, lowest points within each infrastructure were assumed to be at the zero level, building heights were worked out based on the number of floors, and hence Z-coordinate values for all other points (Fig. $12)$

5. Geometric data were then inserted into the Oracle DBMS - taking into account relationships between entities and associate constraints imposed by foreign keys, value insertion followed the BUILDINGS, PART_GEOMETRIES, OWNERS, and ONWERSHIPS order;

6. Building infrastructures within were divided into several constituent simple solids, each of which was stored as a new record of PART_GEOMETRIES table. According to the format of SOD_GEOMETRY (Oracle 2009), the format and method to store simple solid is explained in Table 2 .

Table 2 Format and method of storing solid geometry in Oracle Spatial (Liu 2013)

\begin{tabular}{|c|c|c|}
\hline Attribute & Value & Description \\
\hline SDO_GTYE & $30083 \mathrm{D}$ & Solid data \\
\hline SDO_SRID & NULL & No geo-reference \\
\hline SDO_POINT & NULL & No point features \\
\hline SDO_ELEM_INFO & $\begin{array}{l}(1,1007,1 \\
1,1006, \mathrm{n} \\
1,1003,1 \\
\mathrm{n}, 1003,1 \\
\quad \ldots)\end{array}$ & $\begin{array}{l}\text { - }(1007,1) \text { - One simple solid } \\
\text { - }(1006, \mathrm{n}) \text { - One external surface consisting of n polygons } \\
\text { - }(1003,1) \text { - Simple polygon with straight line segments } \\
\text { - } \mathrm{n} \text { - indicates the start value for the second polygon in the } \\
\text { SDO_ORDINATE array. }\end{array}$ \\
\hline SDO_ORDINATE & $\begin{array}{l}\left(X_{1}, Y_{1}, Z_{1}\right. \\
\quad \cdots \\
X_{n}, Y_{n}, Z_{n} \\
X_{1}, Y_{1}, Z_{1} \\
\quad \cdots)\end{array}$ & $\begin{array}{l}\text { - }\left(\mathrm{X}_{1}, \mathrm{Y}_{1}, \mathrm{Z}_{1}\right) \text { - The coordinates of the starting point in the } \\
\text { point list of the first polygon; } \\
\text { - }\left(\mathrm{X}_{\mathrm{n}}, \mathrm{Y}_{\mathrm{n}}, \mathrm{Z}_{\mathrm{n}}\right) \text { - The coordinates of the penultimate point in } \\
\text { the point list of the first polygon; } \\
\text { - In order to close the polygon, the last point should be } \\
\text { specified exactly the same as the first one. }\end{array}$ \\
\hline
\end{tabular}

Table 2 above corresponds to the "Set Translation Parameters" window in FME Quick Translator. It summarises both input and output data parameters that can be set in the "Reader" and "Writer" boxes respectively. In Fig. 12 below depicts a screenshot to illustrate the insertion of a polygon's geometric data into PART_GEOMETRY table. As can be seen, in this case the solid ID number is "14" and it belongs to the basic building infrastructure whose ID number in BUILDINGS table is " 1 ". This solid is made of an 
external surface consisting of five polygons. The coordinate values of polygons' vertices are listed in SDO_ORDINATE_ARRAY.

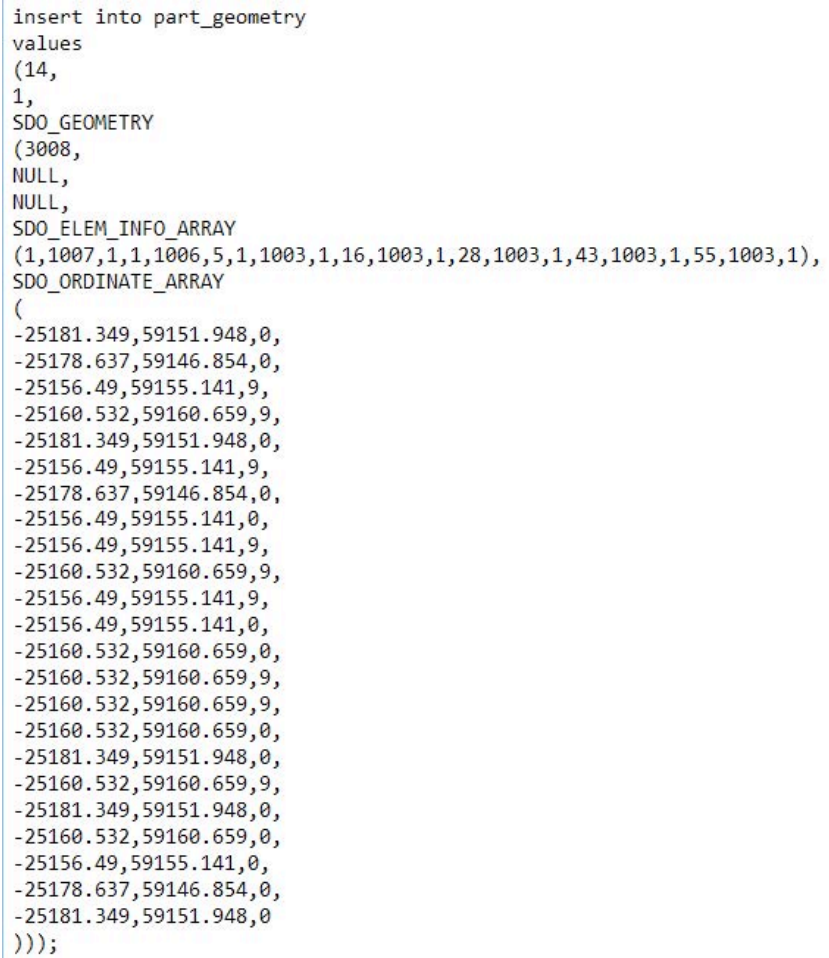

Fig. 12 Example of SQL script referring to the insertion of solid "14" into PART_GEOMETRY table (Liu 2013)

\subsubsection{Preliminary results}

In our case, FME Data Inspector, ArcGIS ArcScene, and GoogleEarth were used in order to visualise the 3D models created in Oracle Spatial. In our case, FME Data Inspector, ArcGIS ArcScene, and GoogleEarth were used in order to visualise the 3D models created in Oracle Spatial. As an example, Fig. 13 depicts visualisation results in GoogleEarth viewer for the case study 6's arch-building (represented in grey). 3D spatial data can be visualised in Google Earth after transforming their format into Google Earth KML and converting the original coordinate system (in our case, Datum 73-IPCC) into WGS 84. Based on GoogleEarth functionalities, users can navigate GoogleEarth viewer in several different ways. Also users are allowed to change the view to ground, street, and terrain level (Google 2013). By double clicking the object's name in the places window (on the left-hand side), it is possible to zoom in to the selected object and its attributes will pop-up in a small floating window (Fig. 14). 


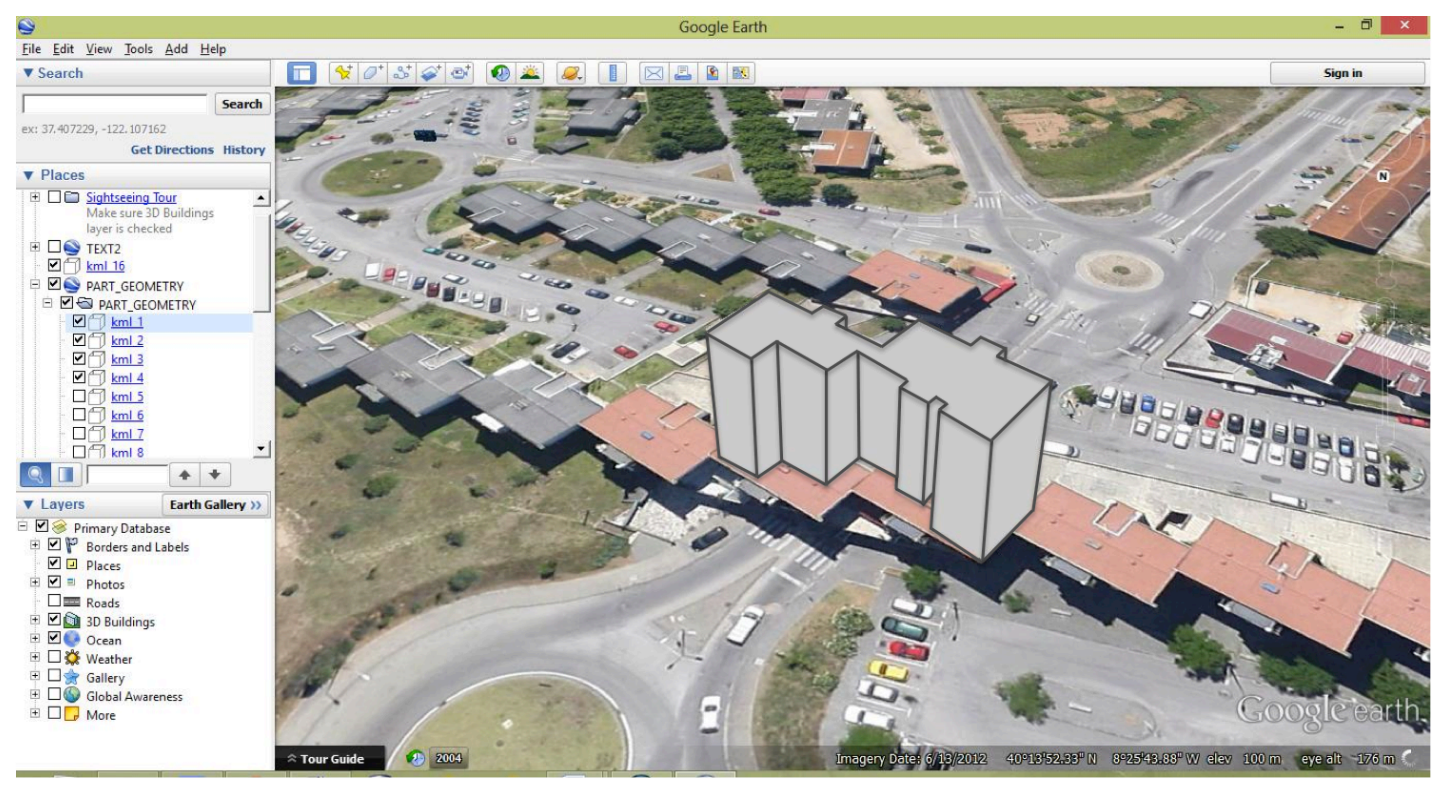

Fig. 13 Visualisation of 3D cadastral data model in GoogleEarth: case study 6's arch-building (Liu 2013)

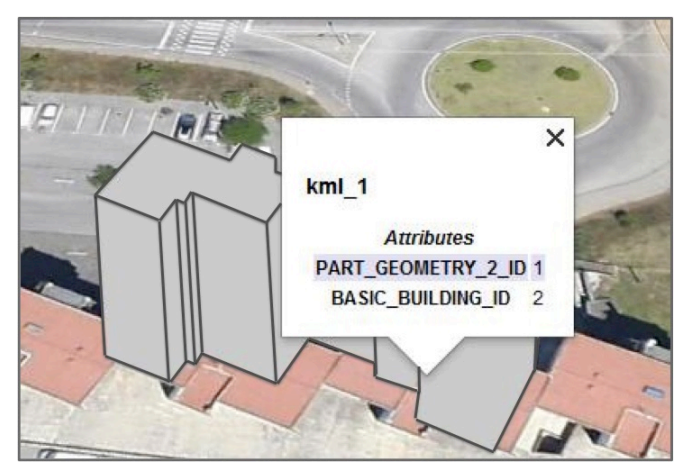

Fig. 14 Popup window displaying attributes of object 1 in PART_GEOMETRY table (Liu 2013)

In terms of 3D modelling results, we shall refer to case study 6 where more interesting 3D modelling issues arose. According to the Portuguese cadastral legislation, spaces underneath and above manmade infrastructures belong (in principle) to the infrastructures' owner(s). In case study 6, there are however exceptions to the general law above. According to the general rule above, subterranean space underneath and airspace above the building infrastructure (in yellow dashed-lines, Fig. 15) constitute private domain belonging to the owner(s) of the infrastructure. However, as pointed out indeed in section 3.3.1.6, the arch-building happens to be constructed over a public road, and hence condominium ownership rights within the volume arch area (in red-dashed lines) are restricted as this constitutes public domain along with the road running under the arch-building. 


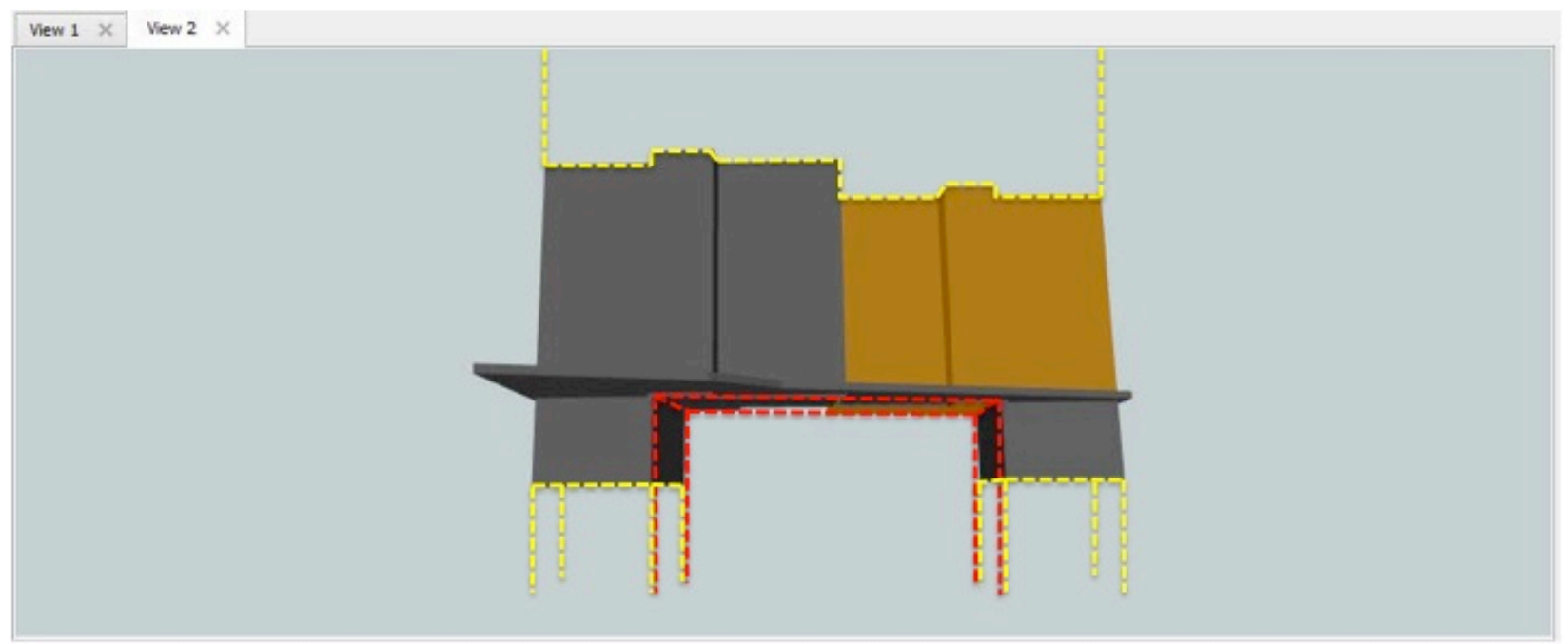

Fig. 15 Example of 3D cadastral modelling issues in case study 6: air and subterranean volume spaces in yellow dashed lines (private domain) need to be modelled; air/subterranean volume space in red dashed lines (public domain) constitutes an exception to the general cadastral law and needs to be modelled too

Simple visual observations of the 3D model above revealed that our modelling approach is not able, at this development stage, to reflect legal requirements above. Different sorts of spaces have to be considered since both airspace and subterranean areas must be adequately described and modelled too.

\section{Conclusions}

\subsection{Final considerations}

A 3D cadastral framework consists of concepts, functionalities, and techniques within which a modern approach is typically a computer-based and multipurpose land administration system. Three key aspects can be specified as follows: cadastral surveying and mapping, legislation, and stakeholders. It is within this context that each national/state context should be modelled based on its specific legislation and potential stakeholders involved.

The main reasons of the need for a more sophisticated modelling approach towards $3 \mathrm{D}$ cadastral systems of land registration and management may be summarised as follows:

- Materialisation of legal ownership concepts within a 3D geometry structure, particularly needed to handle exceptional 3D occurrences to the cadastral law

- 3D visualisation capabilities for both authorities and general public, particularly of exceptional occurrences above.

After reviewing related work on property cadastre 3D modelling, Portugal's historical and current property cadastre situations were revisited. Opportunities within Portugal's context were sought by indentifying six different case studies in which a 3D modelling approach revealed to be pertinent. Case studies were used as the basis for development purposes of a 3D model prototype. Our first research steps mainly focused on the three-level data modelling: conceptual, logical, and physical. First implementation tests focused principally on technical solutions for $3 \mathrm{D}$ cadastre, nevertheless legislation and institutional 
are still significantly important and need to be paid more attention. Portugal cannot currently embark in a full nationwide 3D cadastre for this is not supported yet by the country's cadastral legislation; even so, for the time being a full 3D cadastral law was assumed for the investigation on implementation purposes.

Finally, although the complexity of each system largely depends on legal and institutional circumstances, technological approaches available, and users' demand, discussion and research on 3D cadastre should be accomplished from an international perspective, as it would provide global experience and guidelines in order to facilitate the development process (FIG 1995). Although Portugal's context is in fact the ultimate aim of our research, our case studies hereby presented were sought and discussed from the international perspective above namely foreseeing possible similar instances across the world.

\subsection{Issues and recommendations}

Preliminary implementation tests revealed three major issues. Firstly, geospatial data used in our case studies are not fully adequate for 3D cadastre purposes; in fact, 2D data were mostly used and third dimension data were derived from other sources of data. Secondly, each national/federal/state's cadastral legislation must reflect 3D situations upon which any conceptual modelling should be based; as stated above, a full 3D cadastral law was assumed in our case for investigation purposes and hence our prototype model does not fully match current Portuguese cadastral legislation as it stands. Thirdly, our approach does not cover the concept of both "airspace" and "subterranean" blocks. As to this aspect, a fifth and a sixth entities should have been possibly considered and added to Table 1; indeed, as well as BUILDING entities, an airspace block or subterranean block may well be made of one or more PART-GEOMETRY entities.

Further to our preliminary case study implementation tests, it should be empathised that accurate collection methods of 3D spatial data are absolutely required so that relevant data acquired at a specific time may be incorporated in a 3D data infrastructure. In addition, both legal and institutional aspects should be studied together alongside with technical aspects. Furthermore, the modelling and description of the entire 3D space with no gaps is needed for the full achievement of a 3D modelling approach. This idea may well be seen as an extension of the equivalent concept in 2D polygon contiguity topology where neither gaps nor overlaps are allowed; thus, besides manmade infrastructures, other physical spaces have to be considered, namely airspace and subterranean 3D blocks. As a general recommendation, we shall say then that any conceptual model should take into account physical spaces as well as legal/institutional spaces. As far as physical spaces are concerned, we hereby propose irrespectively of the country the consideration of namely:

- Manmade infrastructures (e.g. buildings)

- Airspace blocks (e.g. above buildings)

- Soil subterranean blocks (e.g. underneath buildings)

each of which may be made of one or more part-geometries. As attributes of the physical spaces above, these may be described in turn as namely:

- Private domain

- State/Federal/Municipal domain

- Public domain

Given a specific cadastral context, legal/institutional spaces above may be adjusted accordingly. 
Finally, and given Portugal's SiNErGIC specific context, a full new modelling approach may not be required at the current stage. Due to the highly increasing costs of "in situ" cadastral surveying, 3D situations may well be integrated when needed by the existing 2D cadastral system so that not every single infrastructure has to be surveyed in 3D. Referring back to the 3D cadastral modelling approaches proposed by Stoter and van Oosterom (2006), reviewed in section 2.2, we strongly believe that the hybrid model would suit to a considerable extent the country's multifunction cadastre purposes.

\section{References}

Abdul-Rahman A, Van Oosterom P, Chee Hua T, Sharkavi K H, Duncan E E, AzriI N, Hassan I (2012) 3D Modelling for Multipurpose Cadastre. $3^{\text {rd }}$ International Workshop on 3D Cadastres: Developments and Practices, Shenzhen, China, 25-26 October 2012.

Abdul-Rahman A, Hua T H, Van Oosterom P (2011) Embedding 3D into Multipurpose Cadastre. FIG working week, Marakech, Marroco, 18-22 May 2011.

Barros-de-Souza G H (2011) Método de Modelagem da Parcela Espacial para o Cadastro Tridimensional (PhD thesis, unpublished). Universidade Estadual Paulista, São Paulo, Brasil.

Brugman B, Tijssen T, van Oosterom P (2011) Validating a 3D topological structure of a 3D space partition. In: Geertman S, Reinhardt W, Toppen F (eds) Advancing Geoinformation Science for a Changing World, Lecture Notes In Geoinformation and Cartography 1. Springer-Verlag, Berlin, Heidelberg, pp 359-378.

Bydłosz J (2012) The 3D Cadastre Aspects in International Standards and Solutions [online]. Available from: http://www.gdmc.nl/3dcadastres/literature/3Dcad_2012_28.pdf [Accessed 20 Jan 2014].

Chong C S (2006) Toward a 3D Cadastre in Malaysia - An Implementation Evaluation. Delft University of Technology, 110.

DGT (2012). Instituto Geográfico Português. www.igeo.pt [Accessed 28 Dec 2013].

Ellul C, Haklay M, Bevan T (2005) Deriving a Generic Topological Data Structure for 3D Data. In: Billen R, Drummond J, Forrest D, João EM (eds) Proceedings of GISRUK $2005-13^{\text {th }}$ Annual Conference, Glasgow, Scotland, 6-8 April 2005.

Ellul C, Haklay M (2006) Requirements for Topology in 3D GIS. In Transactions in GIS 10(2): pp 157175. Wiley Online Library.

Ellul C, Haklay M (2009) Using a B-Rep Structure to Query 9-Intersection Topological Relationships in 3D GIS - Reviewing the Approach and Improving Performance. In: Lee J, Zlatanova S (eds) 3D Geoinformation Sciences, Lecture Notes in Geoinformation and Cartography, Part II. Springer-Verlag, Berlin, Heidelberg, pp 127-151.

FIG (1995) The FIG Statement on the Cadastre. Technical Report Publication No. 11, Federation International de Géomètres, Commission 7 [online]. Available from www.fig.net/commission7/reports/cadastre/statement_on_cadastre.html [Accessed 30 Oct 2012].

Frédéricque B, Keith, Raymond K, Van Prooijen K (2011) 3D GIS as Applied to Cadastre - a Benchmark of Today's Capabilities. FIG Working Week, Marrakech, Morocco, 18-22 May 2011.

Gröger G, Plümer L (2005) How to Get 3D for the Price of 2-D - Topology and Consistency of 3D Urban GIS. Geoinformatica 9.2, pp. 139-158. 
Gröger G, Plümer L (2011a) How to achieve consistency for 3D city models. Geoinformatica 15, pp. 137165.

Gröger G, Plümer L (2011b) Topology of Surfaces Modelling Bridges and Tunnels in 3D GIS. Computers, Environment and Urban Systems, 35(3): 208-216.

Guo R, Ying S, Li L, Luo P, He B, Zhao Z (2011) 3D Cadastre in China - a case study in Shenzhen city. In: Pouliot J, Daniel S, Hubert F, Zamyadi A (eds) Proceedings of $2^{\text {nd }}$ International Workshop on 3D Cadastres. Delft, The Netherlands, 16-18 November 2011.

Hassan M I, Abdul-Rahman A (2010) Malaysian Integrated 3D Cadastre Registration System. FIG Congress, Sidney, Australia, 11-16 April 2010, p14.

Hespanha J P, Van Oosterom P, Zevenbergen J, Paiva-Dias G (2006) A Modular Standard for Cadastral Domain - Application to the Portuguese Cadastre. Computers, Environment and Urban Systems, 30(5): 562-584.

ISO/TC211 (2012) Geographic information - Land Administration Domain Model, ISO/FDIS 19152.

Jeong D, Kim T, Nam D, Li H, Cho H (2011) A Review of 3D Cadastre Pilot Project and the Policy of 3D NSDI in the Republic of Korea. In: Pouliot J, Daniel S, Hubert F, Zamyadi A (eds) Proceedings of $2^{\text {nd }}$ International Workshop on 3D Cadastres. Delft, The Netherlands, 16-18 November 2011.

Karki S, Thompson R, McDougall K (2011a) Data validation in 3D cadastre. In: Neutens T, de Maeyer P (eds) Developments in 3D Geoinformation Sciences, Lecture Notes in Geoinformation and Cartography. Springer-Verlag, Berlin, Heidelberg, pp. 92-122.

Karki S, Thompson R, McDougall K, Cumerford N, Van Oosterom P (2011b) ISO Land Administration Domain Model and LandXML in the Development of Digital Survey Plan Lodgement for 3D Cadastre in Australia. In: Pouliot J, Daniel S, Hubert F, Zamyadi A (eds) Proceedings of $2^{\text {nd }}$ International Workshop on 3D Cadastres. Delft, The Netherlands, 16-18 November 2011.

Kazar B M, Kothuri R, Van Oosterom P, Ravada S, 2008. On Valid and Invalid Three-Dimensional Geometries. In van Oosterom P, Penninga F, Zlatanova S, Fendel E (eds) Advances in 3D Geoinformation Systems, Lecture Notes in Geoinformation and Cartography. Springer-Verlag, Berlin, Heidelberg.

Khoo V H S (2012) Towards "Smart Cadastre" that Supports 3D Parcels. 3rd International Workshop on 3D Cadastres: Developments and Practices, Shenzhen, China, 25-26 October 2012.

Lemmen C, van der Molen P, van Oosterom P, Ploeger H, Quak W, Stoter J, Zevenbergen J (2003) A Modular Standard for the Cadastral Domain. In Proceedings of $3^{\text {rd }}$ International Symposium on Digital Earth, Brno, Czech Republic, September 2003, pp. 399-419.

Lemmen C, van Oosterom P, Thompson R, Hespanha J P, Uitermark H (2010) The Modelling of Spatial Units (Parcels) in the Land Administration Domain Model (LADM). FIG Congress, Sidney, Australia, 1116 April 2010.

Lemmen C (2012) A Domain Model for Land Administration. Publications on Geodesy, 78. NCG, Delft, The Netherlands.

Liu X (2013) Make the Case for 3D Cadastral Systems in Portugal. MSc dissertation in Geographic Information Science (unpublished). Dpt. of Civil, Environmental \& Geomatic Engineering, University College London, London, UK, pp. 19-36. 
Manthorpe J (2004) Comparative Analysis of Cadastral and Land Administration Systems in the United Kingdom. Comparative Analysis on the Cadastral Systems in the European Union. The European Union Permanent Committee on Cadastre.

Mendes IP (2003) Estudos sobre Registo Predial. Editora Almedina, Coimbra, Portugal.

Ng'ang'a S, Sutherland M, Cockburn S, Nichols S (2004) Toward a 3D marine cadastre in support of good ocean governance: a review of the technical framework requirements. Computers, Environment and Urban Systems, 28(5): pp. 443-470.

Oracle (2009) Spatial Developer's Guide. Spatial Concepts. 11g Release 1 (11.1) [online]. Available from: http://docs.oracle.com/cd/B28359 01/appdev.111/b28400/sdo_intro.htm and http://docs.oracle.com/cd/B28359 01/appdev.111/b28400/sdo objrelschema.htm\#i1004087 [Accessed 20 August 2013].

PCM-Presidência do Conselho de Ministros (2006) Resolução do Conselho de Ministros nr. 45. Diário da República Portuguesa, Série I-B, $\mathrm{Nr}^{\circ}$. 86, 4 de maio.

PCM-Presidência do Conselho de Ministros (2012a) Resolução do Conselho de Ministros nr. 56. Diário da República Portuguesa, Série I, Nrº 129, 5 de julho.

PCM-Presidência do Conselho de Ministros (2012b) Resolução do Conselho de Ministros nr. 70. Diário da República Portuguesa, Série I, Nrº 164,24 de agosto.

Silva MJ, Bessa MI, Machado V, Clode L (2005) Breves notas sobre os procedimentos legais conducentes à primeira inscrição no registo predial português, e à regularização fundiária no âmbito das operações urbanísticas”. XV Congresso Internacional de Direito Registral, Fortaleza, Brasil, 7-10 November 2005.

Smith JA (2012) Building Information Model - A Contractors Perspective. In International Federation of Surveyors, article of the month - June 2012.

Soon KH (2012) A conceptual framework of representing semantics for 3D cadastre in Singapore. $3^{\text {rd }}$ International Workshop on 3D Cadastres: Developments and Practices, Shenzhen, China, 25-26 October 2012 .

Steudler D, Rajabifard A, Williamsin I (2004) A worldwide comparison of cadastral systems (Working sheet, not published). The 'Permanent Committee on GIS Infrastructure for Asia \& the Pacific' (PCGIAP) Working Group 3; The 'International Federation of Surveyors' (FIG) - Working Group 7.

Stoter J (2004) 3D Cadastre. In Publications on Geodesy, 57. NCG, Delft, The Netherlands.

Stoter J, van Oosterom P, Ploeger J, Hendrik D, Aalders H (2004) Conceptual 3D Cadastral Model Applied in Several Countries in TS25 - Appropriate Technologies for Good Land Administration II - 3D Cadastre. FIG Working Week, Athens, Greece, 22-27 May 2004.

Stoter J, van Oosterom P (2006) 3D Cadastre in an International Context: Legal, Organizational, and Technological Aspects. Taylor \& Francis, Boca Raton (FL), USA.

Stoter J (2011) Geoprofessionals should look outside their own box [online]. GIM International, 25(12).

Available from http://www.gim-international.com/issues/articles/id1794-

Geoprofessionals_Should_Look_Ouside_Their_Own_Box.html [Accessed 20 Nov 2012]. 
Stoter J, Ploeger H, Louwman W, van Oosterom P, Wünsch B (2011) Registration of 3D Situations in Land Administration in The Netherlands. In: Pouliot J, Daniel S, Hubert F, Zamyadi A (eds) Proceedings of $2^{\text {nd }}$ International Workshop on 3D Cadastres. Delft, The Netherlands, 16-18 November 2011.

Stoter J, Beets J, Ledoux H, Reuver M, Klooster R, Janssen P, Penninga F (2012a) Towards mainstream geographical data [online]. Geospatial World Forum, Amsterdam, The Netherlands. Available from http://beta.geospatialworld.net/Regions/ArticleView.aspx?aid=25159 [Accessed 21 Nov 2012].

Stoter J, van Oosterom P, Ploeger H (2012b) The phased 3D cadastre implementation in the Netherlands. 3rd International Workshop on 3D Cadastres: Developments and Practices, Shenzhen, China, 25-26 October 2012.

Thompson R, van Oosterom P (2011) Modelling and validation of 3D cadastral objects. UDMS, Delft, The Netherlands, 28-30 September 2011.

Thompson R, van Oosterom P (2011) Axiomatic Definition of Valid 3D Parcels, potentially in a Space Partition. In: Pouliot J, Daniel S, Hubert F, Zamyadi A (eds) Proceedings of $2^{\text {nd }}$ International Workshop on 3D Cadastres. Delft, The Netherlands, 16-18 November 2011.

Valstade T (2005) 3D Cadastres in Europe - Norway. Cadastral Infrastructure, Bogota, Colombia, 22-24 November 2005.

Vandysheva N, Ivanov A, Pakhomov S (2011) Design of the 3D Cadastre Model and Development of the Prototype in the Russian Federation. In: Pouliot J, Daniel S, Hubert F, Zamyadi A (eds) Proceedings of $2^{\text {nd }}$ International Workshop on 3D Cadastres. Delft, The Netherlands, 16-18 November 2011.

van Oosterom P, Stoter J, Ploeger H, Thompson R, Karki S (2011) World-wide Inventory of the Status of 3D Cadastres in 2010 and Expectations for 2014. FIG Working Week, Marrakech, Morocco, 18-22 May 2011.

Verbee E, Si H (2008) Validation and storage of polyhedra through constrained Delaunay tetrahedralization. In: Cova TJ, Miller HJ, Beard K, Frank AU, Goodchild M (eds) GIScience 2008 LNCS 5266. Springer-Verlag, Berlin, Heidelberg, pp. 354-369.

Wang C, Pouliot J, Hubert F (2012) Visualization principles in 3D cadastre: a first assessment of visual variables. $3^{\text {rd }}$ International Workshop on 3D Cadastres: Developments and Practices, Shenzhen, China, 2526 October 2012.

Ying S, Guo R, Li L, He B (2012) Application of 3D GIS to 3D cadastre in urban environment. $3^{\text {rd }}$ International Workshop on 3D Cadastres: Developments and Practices, Shenzhen, China, 25-26 October 2012 .

Yavuz A (2005) A Comparative Analysis of Cadastral Systems in the EU Countries According to Basic Selected Criteria. "From Pharaohs to Geoinformatics", FIG Working Week 2005 and GSDI-8, Cairo, Egypt, 16-21 April 2005.

Zhao Z, Guo R, Li L, Ying S (2012) Topological relationship identification in 3D cadastre. $3^{\text {rd }}$ International Workshop on 3D Cadastres: Developments and Practices, Shenzhen, China, 25-26 October 2012.

\section{Acknowledgements}


"European Science Foundation ", which funded this work through two COST short-term scientific mission grants: STSM-TU0801-170912-022642 and STSM-IC1203-011013-035368.

"Fundação para a Ciência e Tecnologia", FCT (Portugal's research council), which partially supported this work through PEst-C/EEI/UI0308/2011 project grant. 